\title{
The Relationship Between Dividend Payments And Firm Performance: A Study Of Listed Companies In Morocco
}

\author{
Dr. Rachid M'rabet \\ Wiame Boujjat
}

Ph.D Candidate \& Finance Researcher - ISCAE Casablanca

Department of Finance, Institut Supérieur de Commerce et d'Administration des Entreprises, Morocco

doi: 10.19044/esj.2016.v12n4p469 URL:http://dx.doi.org/10.19044/esj.2016.v12n4p469

\begin{abstract}
Many theories have been documented on the relevance and irrelevance of dividend policy. Authors continue to come up with various conclusions with regard to dividend policy from their empirical studies. This paper sought to examine the relationship between dividend policies and financial performance of selected listed firms in Morocco. Data were sourced through secondary means from the annual reports of the sampled quoted firms and was analyzed using panel data regression model. Two models were developed in an attempt to provide a theoretical explanation on the birds-in-hand dividend relevance theory and the Modigliani and Miller's (MM) dividend irrelevance theory. The findings indicated that Dividend policy is an important factor affecting firm performance. Their relationship was also strong and positive. This therefore showed that dividend policy was relevant. It can be concluded, based on the findings of this research that dividend policy is relevant and that managers should devote adequate time in designing a dividend policy that will enhance firm performance and therefore shareholder value. Management of companies should also invest in projects that give positive Net Present Values, thereby generating huge earnings, which can be partly used to pay dividends to their equity shareholders.
\end{abstract}

Keywords: Dividend policy, firm performance, Casablanca Stock Exchange

\section{Introduction}

With a market capitalization in excess of $\$ 60.0$ billion at year end 2011, Casablanca Stock Exchange (CSE) is the second largest securities exchange in Africa. Founded in 1929, it is the third oldest exchange in the 
African continent as well. The Casablanca Stock Exchange currently has 77 listed companies. The listed stocks are categorized into three equity markets: the Main Market, the Development Market, and the Growth Market. They are classified into different sectors. These are: Construction \& Building Materials, Oil \& Gas, Insurance, Real Estate, Construction \& Building Materials, Banks, Distributors, Investment Companies \& Other Finance, Beverages, Food producers \& Processors, Transport, Engineering \& Equipment Industrial Goods, Holding Companies, Materials, Software \& Computer Services, Telecommunications, Utilities, Chemicals, Mining, Forestry \& Paper, Electrical \& Electronic Equipment, Pharmaceutical Industry, Leisures and Hotels and Electricity.

The issue of dividend policy in corporate organization in both developed and developing countries has been of great concern globally. Several theories have been proposed to explain the relevance of dividend policy and whether it affects firm value, but there has not been an universal agreement (see Ashamu, Abiola \& Badmus, 2008). This is more so because managers as decision makers are often confronted with the "dividend puzzle" - which is the problem of reconciling observed dividend behaviour with economic incentives (see also Adeyemi \& Adewale, 2006). Hence, dividend policy is considered as a hinge around which other financial policies rotate. For this reason it is central to the performance and valuation of listed firms. Consequently, there has been an unresolved problem on dividend relevance and/or irrelevance in the determination of firms' performance and value. The question of whether manager should pay out more dividends to owners or retain more of the profit as internal source of financing has also remained unanswered Zhou \& Ruland, 2006).

A number of empirical studies (Arnott \& Asness 2003; Farsio et al 2004 and Nissim \& Ziv 2001) have looked at the dividend policy and firm performance. The results of previous studies are quite inconsistent; some studies indicate the existence of a relationship between dividend changes and earnings, while others do not find such a relationship. The most important controversies were the two studies by Nissim and Ziv (2001) and Grullon, Michaely, Benartzi and Thaler (2005) that show contrasting results. Nissim and Ziv (2001) find significant support on the information content hypothesis, while Grullon et al. (2005) find results that dividend changes are unrelated to future profitability. This situation leaves the issue unsettled. Hence more studies are needed to provide additional evidence on this topic, including studies in a developing market such as Morocco.

This study aims to examine the possible effect that firm's dividend policy might have on the shareholders' wealth and the resulting impact it could have on the financial performance of listed firms in Morocco. Specifically, the objectives of this study are to: 
- Examine the relationship between the dividend policy and financial performance of quoted firms in Morocco;

- Appraise the effect of dividend payments on the changes in shareholder's fund of listed firms in Morocco.

The remaining part of the study is structured as follows. Section two provides the review of related literature. Section four provides the methodology of the study. The next section presents the research findings. Conclusion and recommendations of the study are found in the last section.

\section{LITTERATURE REVIEW}

Different studies have adopted diverse theories that are relevant in any discourse relating to dividend policy and performance of firms, however, they viewed it from different perspectives depending on the context of their work. Irrespective of the existence of a large number of theories relating to dividend policy, a general consensus has been reached in the literatures that categorize dividend theories into two main categories, these are: dividend relevance theories, and dividend irrelevance theories (Walter, 1963; Van Horne, 1971; Pandey, 1979; Olowe, 1998 etc.). These studies developed relevant models to ascertain the relevance or irrelevance of dividend policy as posited in the bird-in-hand theory and Modigliani and Miller (M\&M) theory respectively. These theories are often used to explain the relationship between dividend, performance and value of firms as previously used in the works of Adefila, Oladipo \& Adeoti (2000); Ashamu, Abiola \& Badmus (2010); and Murekefu \& Ouma (2012).

Figure-1 Dividend Policy Theoretical Framework (S. ALAA, 2010)

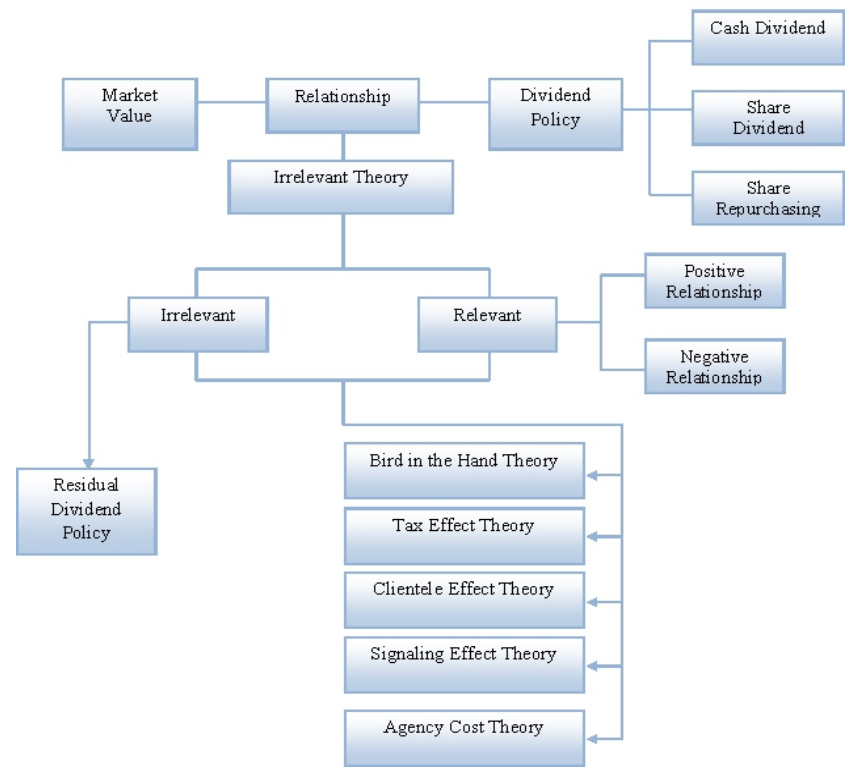




\section{Irrelevance proposition}

Many researchers and economics specialists believe that cash dividend policy is unimportant because it is not relevant and does not affect the owners'wealth. The source of this belief is a study conducted by Miller and Modigliani (1961). This study concludes that dividend policy has no effect on a company's value, and therefore managers will not be able to maximize owners' wealth through a dividend policy. The only thing that impacts the valuation of a company is its earnings, which is a direct result of the company's investment policy and the future prospects. So, once the investment policy is known to the investor, he will not need any additional input on the dividend history of the company. If the investor needs more money than the dividend he received, he can always sell a part of his investments to make up for the difference. Likewise, if an investor has no present cash requirement, he can always reinvest the received dividend in the stock. Despite the importance of this theory, the critics of MM dispute the validity of the dividend irrelevance theorem by challenging the assumptions used by MM. According to the critics such as Lintner (1962) and Gordon (1963), dividends matters because of the uncertainty characterizing the future, the imperfections in the capital market and the existence of taxes.

\section{Relevance propositions}

\subsection{Bird in hand Theory}

Bird in hand theory proposes that a relationship exists between firm value and dividend payout. It states that dividends are less risky than capital gains since they are more certain. Therefore, investors would prefer dividends to capital gains (Amidu, 2007). Because dividends are supposedly less risky than capital gains, firms should set a high dividend payout ratio and offer a high dividend yield to maximize stock price. The essence of the bird-in-the-hand theory of dividend policy (John Litner in 1962 and Myron Gordon in 1963) argues that outside shareholders prefer a higher dividend policy. Consequently, investors would value high payout firms more highly. In addition, when making dividend payouts, the firm gets a higher rating from rating agencies as compared to a firm not making any dividend payout. With a better rating, the firm will be able to raise finance more easily from capital markets since credit institutions will be willing to give loans to the firm since the payout of dividends shows that the firm has the ability to meet its obligations. In some cases, the firm will be able to borrow at preferential rates and enjoy better facilities.

\subsection{Tax effect theory}

Tax preference theory was first developed by Litzenberger and Ramaswamy. This theory claims that investors prefer lower payout 
companies for tax reasons. Litzenberger and Ramaswamy based this theory on observation of American stock market. They presented three major reasons why investors might prefer lower payout companies. Firstly, unlike dividend, long-term capital gains allow the investor to defer tax payment until they decide to sell the stock. Because of time value effects, tax paid immediately has a higher effective capital cost than the same tax paid in the future. Secondly, up until 1986 all dividend and only 40 percent of capital gains were taxed. At a taxation rate of $50 \%$, this gives us a $50 \%$ tax rate on dividends and $(0,4)(0,5)=20 \%$ on long-term capital gains. Therefore, investors might want the companies to retain their earnings in order to avoid higher taxes. As of 1989 dividend and capital gains tax rates are equal but deferral issue still remains. Finally, if a stockholder dies, no capital gains tax is collected at all. Those who inherit the stocks can sell them on the death day at their base costs and avoid capital gains tax payment.

\subsection{Clientele effect theory}

Black and Scholes (1974) found that each investor has his/her own implicit calculations regarding preference between high cash dividends benefits or their retention according to the circumstances he/she is experiencing such as the tax category into which he/she falls. As a result, some investors prefer companies with high cash dividends, whereas others prefer companies with low cash dividends or without any cash dividends and retention of profits for investment. In other words, investors will invest only in companies which have dividend policy consistent with their special desires, requirements and conditions. Thus, a firm that pays no or low dividends should not be penalized for doing so, because its investors do not want dividends. Conversely, a firm that pays high dividends should not have a lower value, since its investors like dividends. This argument assumes that there are enough investors in each dividend clientele to allow firms to be fairly valued, no matter what their dividend policy is. This is known as the Clientele Effect.

\subsection{Agency theory}

The agency cost theory suggests that, dividend policy is determined by agency costs arising from the divergence of ownership and control. Managers may not always adopt a dividend policy that is value-maximizing for shareholders but would choose a dividend policy that maximizes their own private benefits and personal interests. Since shareholders are aware of this fact, they may develop means of controlling managers'behaviours (Jensen and Meckling, 1976, Fama and Jensen, 1983, Jensen, 1986, Shleifer and Vishny, 1997). Making dividend payouts will reduce the free cash flows available to the managers and consequently ensures that managers maximize 
shareholders' wealth rather than using the funds for their private benefits (DeAngelo, H., \& DeAngelo, L., 2006).

\subsection{Signaling Theory}

Managers use the change in cash dividends distributed rates as a mean to deliver information to investors about the company. The intuition underlying this argument is based on the information asymmetry between managers (insiders) and outside investors, where managers have private information about the current and future fortunes of the firm that is not available to outsiders. Here, managers are thought to have the incentive to communicate this information to the market. Bhattacharya (1979), John and William (1985), and Miller and Rock (1985) argued that information asymmetries between firms and outside shareholders may induce a signaling role for dividends. They show that dividend payments communicate private information in a fully revealing manner. The most important element in their theory is that firms have to pay out funds regularly. An announcement of dividends increase is taken as good news and accordingly the share price reacts favorably, and vice-versa. Only good-quality firms can send signals to the market through dividends and poor quality firms cannot mimic these because of the dissipative signaling cost (for e.g. transaction cost of external financing, or tax penalty on dividends, distortion of investment decisions).

\section{Empirical review}

The behavior of dividend policy is one most controversial issue in the corporate finance literature and still keeps its prominent place in world markets (Hafeez \& Attiya, 2009). Many researchers have tried to uncover issues regarding the dividend dynamics and determinants of dividend policy but we still don't have a unified explanation for the observed dividend behavior of firms (Black, 1976; Brealey \& Myers 2005). Dividend policy has been analyzed for many decades, but no universally accepted explanation for companies' observed dividend behavior has been established (Samuel \& Edward, 2011). It remains one of the top ten most difficult unsolved problems in financial economics.

Because dividends reduce the funds available for investment, many market observers and investors associate high dividend payout with weak future earnings growth. Zhou and Ruland (2006) provided evidence that contradicts that view. They conducted an analysis of a large sample of companies and found that a strong positive relationship exists between current dividend payout and future earnings growth, with the positive relationship being more prominent for companies with limited growth opportunities or a tendency towards overinvestment. Their findings are corroborated by Nissim and Ziv (2001) who studied the dividend events 
between the period of 1963 to 1998 and found that dividend increases usually indicate increases in future profitability although dividend decreases are not correlated with future earnings.

The findings of another study done by Arnott \& Asness (2003) also revealed that future earnings growth is associated with high rather than low dividend payout. They concluded that historical evidence strongly suggests that expected future earnings growth is fastest when current payout ratios are high and slowest when payout ratios are low. Their evidence contradicted the view that substantial reinvestment of retained earnings would fuel faster future earnings growth.

Gwilym, Seaton, Suddason and Thomas (2006) extended the analysis of Arnott and Asness (2003) to 10 other international markets including France, Germany, Greece, Italy, Japan, the Netherlands, Portugal, Spain, Switzerland, and the United Kingdom, and found that despite different institutional, tax and legal environments across the countries, international evidence generally supported the findings of Arnott et al (2003) that substantial reinvestment of retained earnings does not lead to faster future real earnings growth.

Some other studies like Fersio, Geary \& Moser (2004) are of the view that dividend policy is not relevant in determining the value or measuring performance of firms. They rather believe that substantial reinvestment of retained earnings (as against dividend payout) would enhance faster earnings growth in the future. For instance, Fersio et al point out that an increase in dividends may lead to a decline in funds that are to be reinvested by the firm. Firms that pay high dividends without considering investment needs may therefore experience lower future earnings. Another scenario is that an increase in dividends may be the result of the management's policy to keep investors satisfied and prevent them from selling the stock at times when future earnings are expected to decline or current losses are expected to continue. There is a negative relationship between dividend payout and future earnings.

Similar studies are still scarce in the emerging markets. In Kenya, Murekefu \& Ouma (2012) support the dividend relevant advocates. Their study examines the relationship between dividend payout and the performance of firms measured by the net profit after tax for the period 2002 and 2010. The study uses regression analysis to run the secondary data gathered from the financial statement of 41 listed companies and the findings show that dividend payout is a major factor affecting firms' performance, thereby support the bird-in-hand theory; that investors will appreciate what they can see as real earnings (inform of cash dividend) than accumulated wealth which can be affected by inflation. 
U Uwuigbe (2012) basically investigates the relationship between the financial performance and dividend payout among listed firms' in Nigeria. The annual reports for the period 2006-2010 were utilized as the main source of data collection for the 50 sampled firms. The regression analysis method was employed as a statistical technique for analysing the data collected. The results show that there is a significant positive association between the performance of firms and the dividend payout of the sampled firms in Nigeria.

Ijaiya \& al (2013) basically investigate the relationship between the financial performance and dividend payout among listed firms' in Nigeria. The result from their findings shows an insignificant relationship between dividend payout ratio and financial performance of the selected quoted firms in Nigeria from the first model, while the result from the second model shows a significant but inverse relationship between dividend payout ratio and earnings per share, implying that companies retained earnings as a means of increasing their earnings per share. Based on the findings, the study recommends that firms should maintain a reduced but stable dividend payout in order to increase internal finance, market valuation and in the long run maximizes the shareholder wealth.

Reza Raei (2012) conducts an empirical test of signaling theory. Based on sampling, 88 firms from Tehran Stock Exchange (TSE) were selected and examined during 2003 to 2010, the aim of his study is preparing the evidence on dividend signaling about corporate operating characteristics (return, performance and earning. Therefore, linear regression models were fitted. Results showed that significantly positive correlation exists between dividend and return. Also, there was a similar relationship between dividend and earning. It means that dividend has information content about return and earning and so, signaling theory was approved about them. Nonetheless, a significant relationship was not funded between dividend and performance proxies (return on assets and market to book ratio) and so, signaling theory was not approved.

M. Amidu (2007) examined the financial position of the companies and the relationship between financial position and profitability measured by the return on assets on the sample of listed firms on the Ghana Stock exchange during the eight-year period (1997-2004). The results show that dividend payout has a strong and significant impact on firms' profitability and concluded that dividend payout was a major factor affecting firm's performance.

Recently in Pakistan, Mudassar Hasan (2015) investigates the relationship between dividend payout ratio and profitability of a firm. For this, two main sectors of Pakistan are selected, energy and textile. The study covers a time span of 1996-2008. Firm performance is measured by earning 
per share (EPS) and return on assets (ROA). The results of logarithmic regression show that no matter what industry is, there is a negative impact of dividend payout ratio on next year earnings of a firm. These results are very surprising and giving new dimensions to the finance researchers to further study in this area and find out the insights.

\section{III- CONCEPTUALIZATION}

This research will be an explanatory study. The emphasis here is on studying a situation or a problem in order to explain the relationship between variables. Our methodology is similar to Ouma’s study (2012).

\section{Figure- 2: Author Constructed}

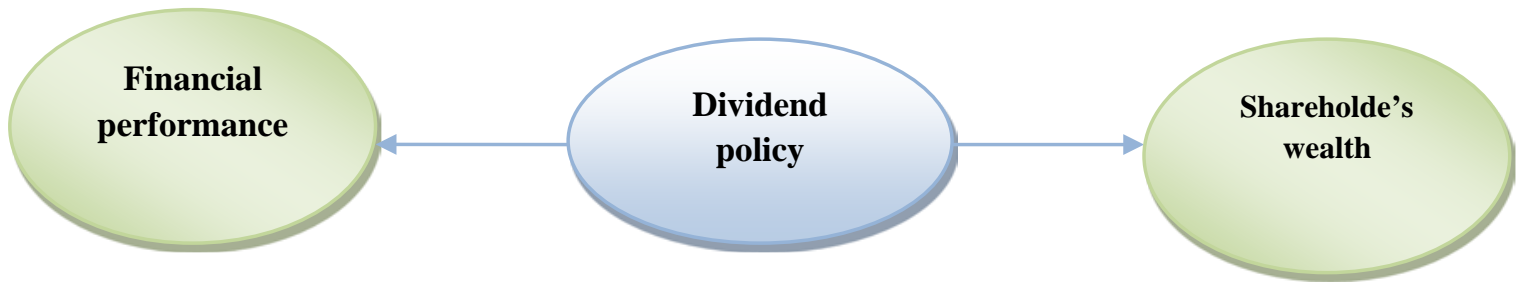

\section{IV- HYPOTHESIS OF THE STUDY}

In achieving the objectives of the study, the following hypotheses were tested:

H1: There significant relationship between the dividend payments and the financial performance of quoted firms in Morocco.

H2: The relationship between the changes in dividend payments and the changes in shareholders' wealth of listed firms in Morocco is statistically significant.

\section{V- METHODOLOGY}

\section{1- Source of data}

The study used secondary data for the analysis. The data utilized is extracted from the comprehensive income statements and financial position of companies quoted in Casablanca Stock Exchange (CSE) database. Using the judgmental sampling technique; a total of 44 listed firms operating in different industries were selected. This represents $80 \%$ of the total population. This is to ensure fair representativeness and permit valid generalization of findings. The time frame considered for this study is five (5) years covering the period from 2010 to 2014.

\section{1- Mode of analysis}

Following the work of Ijaiya \& al (2013), this study adopts their model stated in model 1 , while model 2 was built to explain how dividend policy affects financing and value of a firm. 
The model 1 is stated as: PAT(i,t)= $($ DIVP(i,t), TA(i,t))

When transformed the model becomes: PAT $(i, t)=\beta 0+\beta 1 D I V P(i, t)$ $+\beta 2 \mathrm{TA}(\mathrm{i}, \mathrm{t})+\mathrm{e} 1$

Where:

PAT =Profit After Tax (proxy for firms performance).

DIVP = Actual dividends paid (to proxy Dividend Policy).

TA $=$ Total Asset (introduced as a control variable).

$\beta 0, \beta 1$ and $\beta 2=$ Constant and Coefficient of variables respectively.

$\mathrm{e} 1=$ error term and Subscript $(\mathrm{i}, \mathrm{t})=$ the value of the panel data variable "i" in year " $t$ ".

The a-priori expectations for model 1 is such that $\beta 1 \mathrm{DIVP}>0, \beta 2 \mathrm{TA}$ $>0$. This implies that a positive relationship is expected between the explanatory variables and the dependent variable. That is, the more the PAT, the more the DIVP and the more the PAT, the more the TA

The second model is stated below: $\operatorname{MCap}(\mathrm{i}, \mathrm{t})=\mathrm{f}(\mathrm{DIVP}(\mathrm{i}, \mathrm{t}))$

When transformed the model becomes: MCap $(i, t)=\alpha 0+\alpha 1 D I V P(i, t)$ $+\alpha 2 \mathrm{TA}(\mathrm{i}, \mathrm{t})+\mathrm{u} 1$

Where:

MCap=Market capitalisation (proxy for shareholders' wealth).

DIVP = Actual dividends paid (to proxy Dividend Policy).

$\mathrm{TA}=$ Total Asset (introduced as a control variable). $\alpha 0, \alpha 1$ and $\alpha 2=$ Constant and Coefficient of the explanatory variables.

$\mathrm{u} 1=$ error term and Subscript $(\mathrm{i}, \mathrm{t})=$ the value of the panel data variable "i" in year " $\mathrm{t}$ ".

The a priori expectation for model 2 is that $\alpha 1$ DIVP and $\alpha 2$ TA $>0$. This implies that a positive relationship is expected between the explanatory variables and the dependent variable. The rationale for using two models in this paper is also consistent with the work of Ashamu, et. al. (2010) conducted on similar topics.

\section{2- Method of data}

We analyze our data by employing correlation; multiple regression s\& descriptive statistics. For the study, entire analysis is done by personal computer. A well known statistical package like 'Statistical Package for Social Sciences' (SPSS) 18.0 Version was used in order to analyze the data. The following variables are taken into accounts which are given below.

\section{VI- PRESENTATION OF RESULT AND DISCUSSION OF FINDINGS}

The dependent variable of model 1 is Profit after Tax (PAT) which is used as proxy for performance while Dividend Payments (DIVP) as the 
independent variable is used to proxy dividend policy. The Total Asset (TA) is introduced as the control variable. The result of the panel data regression for model 1 is presented in table 3 below:

Table 3: Result of Panel Data Regression Analysis for Model 1

\begin{tabular}{|c|c|c|c|c|}
\hline \multicolumn{5}{|c|}{ Dependent Variable : PAT } \\
\hline Variable & Coefficient & Std Error & t-statistics & Prob \\
\hline $\mathbf{C}$ & -4029678 & 1.145 &,- 352 & ,725 \\
\hline DIVP & ,807 & ,014 & 56,797 & ,000 \\
\hline TA & ,032 & ,002 & 17,753 & ,000 \\
\hline & & & R-squared & ,994 \\
\hline & & & Adjusted R2 & ,988 \\
\hline & & & F-statistic & 7375.065 \\
\hline & & & $\begin{array}{l}\text { Prob (F- } \\
\text { statistic) }\end{array}$ & ,000 \\
\hline
\end{tabular}

As shown in the table, the coefficient of determination (R2) indicates that 98.8 percent of change in PAT is accounted for by the explanatory variables. The adjusted R-squared is the same. This implies that 1,2 percent of changes in PAT are accounted for by other external variables. In the same vein, the probability of F-Statistic of 0.00 implies that the model is significant even at 5 percent level of significance.

The regression result as presented in the table above further revealed a significant relationship between the dividend policy (proxy with the amount of dividend paid) and the financial performance of firms (proxy with Profit After Tax). This relationship is positive. There was also a positive relationship between net profit after tax and total assets.

Consequently, this result is consistent with the relevance of dividend policy; this therefore informed our decision to accept our hypothesis 1 , which states that there is significant relationship between the dividend payout ratio and the financial performance of quoted firms in Morocco. The result further explain that the control variable (total asset with t-Statistics of 0.00) introduced to the model is statistically significant at 1percent level.

Table 4: Result of Panel Data Regression Analysis for Model 2

\begin{tabular}{|l|l|l|r|r|}
\hline \multicolumn{5}{|c|}{ Dependent Variable : MCap } \\
\hline \multicolumn{1}{|c|}{ Variable } & \multicolumn{1}{|c|}{ Coefficient } & \multicolumn{1}{c|}{ Std Error } & \multicolumn{1}{c|}{ t-statistics } & \multicolumn{1}{c|}{ Prob } \\
\hline C & $\mathbf{6 , 0 6 0}$ & $\mathbf{2 , 6 1 6}$ & $\mathbf{2 , 3 1 7}$ & $\mathbf{0 2 2}$ \\
\hline DIVP & $\mathbf{1 2 , 2 5 1}$ & $\mathbf{3 2 4}$ & $\mathbf{3 7 , 7 7 2}$ & $\mathbf{9 , 9 4 5}$ \\
\hline TA & $\mathbf{0 , 4 1 0}$ & $\mathbf{, 0 4 1}$ & R-squared &, $\mathbf{9 7 2}$ \\
\hline & & & Adjusted R2 & $\mathbf{9 7 2}$ \\
\hline & & & F-statistic & $\mathbf{3 0 4 2 , 1 8 5}$ \\
\hline & & & $\begin{array}{l}\text { Prob (F- } \\
\text { statistic) }\end{array}$ & $\mathbf{0 0 0}$ \\
\hline
\end{tabular}


As shown in table 4, the coefficient of determination (R2) indicates that 97,2 percent of change in capitalization is accounted for by the explanatory variables (Dividend payments and Total Assets). Furthermore, the probability of F-Statistic of 0.000 implies that the model is significant.

The regression estimates further revealed that the relationship between the dividend policy (proxy with the Dividend paid) and the Shareholders' wealth (proxy with Market capitalization) is positive and significant at 5 percent level of significance. An increase in dividend payments will lead to a growth in market capitalization; by implication, this will increase All-Share-Index in the Moroccan Stock Exchange Market. This result moreover, complies with our stated expected result with a priori $(\alpha 1$ DIVP $>0)$. The above result also conflicts with the Modigliani \& Miller's theory of dividend irrelevance, which states that shareholders are ultimately indifferent between receiving returns from dividends or capital gain. Consequently, the findings from model 2 actually proffers that more dividend payments enhance shareholders' wealth (measured by Market capitalization). This therefore informed our decision to confirm our hypothesis 2 .

\section{IV- CONCLUSION \& RECOMMANDATION}

This paper examines the impact of dividend policy on firm performance among 44 quoted firms in Morocco. In consideration of how dividend policy can be used as a source of financing and its effect on the shareholders' wealth maximization, the study tested two models using dividend payments as a proxy for dividend policy, and net profit after tax and market capitalization for financial performance and shareholders' wealth respectively. The total asset was introduced to the two models as a control variable. The data, which were extracted from the financial statement of the sampled quoted firms, were analyzed using panel data regression model

The following conclusions can be drawn from the study. Dividends affect firm performance and that this relationship is strong and positive. This, is in agreement with the findings of Murekefu, et al (2012); Amidu (2007); Lazo (1999); Brigham (1995) and Kale and Noe (1990). It therefore shows that dividend policy is relevant and therefore affects the performance of a firm hence its value contrary to theories that view dividend policy as irrelevant. The findings of this research also showed that cash dividends were the most commonly used form of dividend among listed firms in Morocco. Majority of firms did not therefore employ other forms of dividend payments. The positive significant correlation between PAT and TA could imply that investments are financed from external sources with reasonable cost of capital, thereby fostering the expected corporate performance. 
Based on the aforementioned results, the study recommends that organizations should ensure that they have a good and robust dividend policy in place. This will enhance their profitability and attract investments to the organizations. Management of companies should also invest in projects that give positive Net Present Values, thereby generating huge earnings, which can be partly used to pay dividends to their equity shareholders. This will encourage investors (both local and foreign) to have stake in more firms that pay dividends consistently.

In order to improve this study, efforts should be made in the future to increase the time horizon (say for at least twenty years). Furthermore, classification of the firms into specific sectors and deep study of each sector will produce a more robust result.

Future studies can also look more at the determinants of dividend policy and its influence on the Value Creation especially under its two facets Shareholder and Stakeholders.

\section{References:}

OP Ouma (2012), The Relationship between dividend payout and firm performance: A study of listed companies in Kenya, Global European Scientific Journal, May edition vol. 8, No.9

A.Mehta (2012), An Empirical Analysis of Determinants of Dividend Policy Evidence from the UAE Companies, Global Review of Accounting and Finance Vol. 3. No. 1. March 2012. 18 - 31

M.Borges (2009), Is the Dividend Puzzle Solved? ISEG (School of Economics and Management) of the Technical University of Lisbon M. Hasan (2015), Dividend Payout Ratio and Firm's Profitability. Evidence from Pakistan, Theoretical Economics Letters, 2015, 5, 441-44

P. Zhou (2006), Dividend Payout and Future Earnings Growth, Financial Analysts Journal, Vol. 62, No. 3, pp. 58-69, June 2006

M. Amidu (2007), How does dividend policy affect performance of the firm on Ghana Stock Exchange? Investment Management and Financial Innovations, Volume 4, Issue 2, 2007

M. Ijaiya (2013), Dividend Policy and Financial Performance: A Survey of Selected Quoted Firms in Nigeria , University of Ilorin, Ilorin, Nigeria, Vol.17, No.1, pp.19-32, 2013

R. Onanjiri (2014), Dividend Payout and Performance of Quoted Manufacturing Firms in Ghana, Research Journal of Finance and Accounting, Vol.5, No.15, 2014

U. Uwuigbe (2012), Dividend policy and firm performance: A study of listed firms in Nigeria, Accounting and Management Information Systems Vol. 11, No. 3, pp. 442-454, 2012 
A.Ajanthan (2013), The Relationship between Dividend Payout and Firm Profitability: A Study of Listed Hotels and Restaurant Companies in Sri Lanka, International Journal of Scientific and Research Publications, Volume 3, Issue 6, June 2013 